\title{
Clear Cell Odontogenic Carcinoma
}

National Cancer Institute

\section{Source}

National Cancer Institute. Clear Cell Odontogenic Carcinoma. NCI Thesaurus. Code C54300.

A usually aggressive malignant neoplasm arising from tooth-forming tissues. It more often affects older females and more frequently occurs in the mandible. It is characterized by the presence of malignant epithelial cells with clear cytoplasm and a fibrotic stroma formation. It may recur and metastasize. Metastases may occur in the lymph nodes, lungs, and bones. T reatment of choice is resection with clean margins. 